\title{
Antioxidant Activity and Quality Attributes of Ostrich Meat Nuggets as Affected by Addition of Broccoli Powder
}

\author{
Samia El Safy Farag \\ Department of Food Sci. and Tech. , Fac. of Home Economic , Al - Azhar Univ., Tanta, Egypt. \\ Corresponding author E.mail: lenaspp@yahoo.com
}

\begin{abstract}
Natural antioxidants are in great demand today due to both consumer preference and health concerns associated with the use of synthetic antioxidants, so this study was carried out to investigate the antioxidant compounds in broccoli powder (Bp) and to evaluate it as a source of natural antioxidants in ostrich nuggets production. The effect of addition of the $\mathrm{Bp}$ at different levels $(0,2,4,6$ and $8 \%$ ) on the most important of quality criteria (chemical composition, physical and sensory attributes) of ostrich nuggets compared with control and BHA (150 mg/kg) nuggets was investigated. Oxidative activity of Bp and ostrich nuggets contained $\mathrm{Bp}$ was evaluated by $\mathrm{DPPH}$ free radical scavenging , ABTS and ferric reducing power methods. The increased Bp levels resulted in a significant $(p<0.0)$ increase in ash and crude fiber and a decrease in the percentage of moisture, crude protein and fat. Bp had high amounts of polyphenols, flavonoid and glucosinolates $(17.955,56.56$ and $9.15 \mathrm{mg} / \mathrm{g}$, respectively). Broccoli powder was found to delay lipid peroxidation of ostrich nuggets as measured by TBA number, ostrich nuggets contained $\mathrm{Bp}(8 \%)$ has lower TBA value than control and BHA nuggets. Incorporation of broccoli powder resulted in significant decrease in cooking loss and shrinkage of ostrich nuggets and significantly $(p<0.05)$ increased in cooking yield compared with control and BHA nuggets. The results indicated that ostrich nuggets contained Bp at $8 \%$ has high antioxidant activity (DPPH\%, ABTS \% or reducing power) which was higher than the control sample and BHA nuggets. Sensory evaluation of ostrich nuggets indicated that all addition levels were well accepted in all organoleptic properties as compared to control sample. Consequently, it could be concluded that broccoli powder might be used instead of synthetic antioxidants, as the addition of broccoli powder up to $8 \%$ had no adverse effect on the organoleptic properties or without affecting the acceptability of ostrich nuggets. Thiobarbituric acid value and sensory attributes of ostrich nuggets was lower $(p<0.05)$ than control throughout the refrigerated storage at $4^{\circ} \mathrm{C}$ for 15 day. It can be concluded that broccoli powder as a natural source of antioxidants can be recommended to increase the shelf life of food products containing fats and oils, which is safe and can impart health benefits to the consumer. Keywords: Broccoli powder, ostrich nuggets, phenolic compounds, antoxidative activity, $\mathrm{DPPH}, \mathrm{ABTS}$, reducing power, Sensory propertie.
\end{abstract}

\section{INTRODUCTION}

Antioxidants are compounds that can delay or inhibit the oxidation of lipids or other molecules by inhibiting the initiation or propagation of oxidizing chain reactions. The antioxidants activity of phenolic compounds is mainly due to their redox properties, which can play an important role in adsorbing and neutralizing free radicals, quenching singlet and triplet oxygen or decomposing peroxides (Muchuweti et al. 2007). The synthetic antioxidants,i.e. butylated hydroxyl anisole (BHA) and butylated hydroxyl toluene (BHT) are widely used as food additives and very cost effective given a high stability. The use of BHT and BHA in food has been decreased due to their suspected action as promoters of carcinogenesis or possible toxic as well for the general consumer rejection of synthetic food additives (Namiki, 1990). Several studies indicated that the use of synthetic antioxidants has begun to be restricted because of their health risks and toxicity (Farag et al. 2006). 
Natural antioxidants are significant food constituents and serve a number of functions in a human body. High contents of antioxidants may be found in fruits and vegetables as well as in their processed products. Their action is chiefly based on the neutralization of free radicals and on the prevention from oxidation processes (Sikora et al. 2008). Nowadays, there is a strong need for effective antioxidants from natural sources to prevent deterioration of fats and oils (Samarth et al. 2008).

The replacement of synthetic antioxidant by natural one may have benefits due to health implications and functionality such as solubility in both oil and water (Hagerman et al. 1998; Reglero et al. 1999). Vegetable materials contain many compounds with antioxidant activity. Some plants have been studied as sources of potentially safe natural antioxidants for the food industry, various compounds have been isolated, many of them being polyphenols (Hagerman et al. 1998). Some components of extracts isolated from natural sources such as oilseeds, spices, fruits and vegetables have been proven in model systems to be as effective antioxidants, as synthetic antioxidant (Melo et al. 2005), and it is considered important to increase the antioxidant intake in the human diet and one way achieving this is by enriching food with phenolics. The use of natural antioxidants to stabilize meat has gained much attention from consumers because they are considered to be safer than synthetic antioxidants (Jung et al. 2010) such as BHT, TBHQ and BHA.

Natural antioxidants have the ability to increase the antioxidant capacity of the plasma and reduce the risk of certain diseases such as cancer, stroke and cardiovascular diseases (Chanda and Dave, 2009). It has also been reported that these natural antioxidants, especially of plant source, have greater application potential for consumer's acceptability, palatability, stability and shelf life of meat products (Jung et al. 2010).

Broccoli (Brassica oleracea L.) is rich in both nutritional antioxidants, vitamin $\mathrm{C}$ and $\mathrm{E}$ and minerals and non nutritional antioxidants carotenoids, nitrogensulphur derivatives (glucosinlates and isothiocyanates), and phenolic compounds, particularly flavonoids (Faller and Fialho, 2009; Dominguez-Perles et al. 2012 ), which possess both antioxidant and anticancer activities (Podsedek, 2007, Monero et al., 2010). Brassica, cruciferous family (cauliflower, broccoli, cabbage, and brussels sprouts) is known to be a rich sources of antioxidants (Mukherjee et al. 2008; Kim et al. 2013). Also, Bhandari and Kwak (2014) reported that broccoli is a source of health promoting phytochemicals .

Ostrich meat is recognized as a valuable product of high nutritive and dietetic value making these birds important for many livestock industries (Cooper et al. 2008). Internationally, ostrich meat has become an acceptable red meat and is readily found as either fresh meat or at restaurants in many countries. Initially, ostrich was assumed to be a healthy red meat containing low cholesterol (Sales, 1998), low sodium collagen and high polyunsaturated fatty acids and iron, although by now it is accepted that ostrich has cholesterol 
levels similar to other lean meat types and recommended as an alternative to other types of red meat (Hoffman and Mellett, 2003; Zarasvand et al. 2012).

The addition of antioxidants to processed meats is often carried out to counteract the negative effects of processing aids. However, may be desirable to replace these conventional antioxidants with natural antioxidative substances. Recently, various studies reported the incorporation of the vegetables in comminuted meat products with improved quality, health benefits (Bhosale et al., 2011; Mendiratta et al. 2013) and reduced production cost besides their inherent functional properties (Viuda-Martos et al. 2010).

Natural antioxidants are in great demand today due to both consumer preference and health concerns associated with the use synthetic antioxidants. Therefore, the objectives of this study were evaluate the antioxidant potential of broccoli powder in ostrich meat nuggets comparing with BHA and determined the quality attributtes of the ostrich nuggets during refrigerated storage at $4^{\circ} \mathrm{C}$ at 15 day.

\section{MATERIALS AND METHODS Materials:}

Fresh broccoli (Brassica oleracea) was purchased from a local market, Alexandria, washed with clean water and sliced into small pieces. The sliced broccoli was dried in hot air oven at $60^{\circ} \mathrm{C}$ until drying (24 hrs). The dried broccoli was ground in home mixer to make fine powder and packed in polyethylene bags and kept at refrigerator until used.

Fresh ostrich meat was obtained from the Egyptian Company of Ostrich breeding, Cairo, Egypt. The carcass were hot deboned and meat was chilled overnight in refrigerator at $4^{\circ} \mathrm{C}$ and packed under vacuum in polyethylene bags and quickly brought in ice box to the laboratoty and stored under frozen condition $\left(-18^{\circ} \mathrm{C}\right)$ till further use.

Other additivs used were spices mix (white pepper, red pepper, black pepper, nutmeg, cumin), sodium chloride, refined vegetable oil, condiments (garlic powder, onion powder), refined wheat flour and whole egg liquid were obtained from supermarket of Tanta City, Egypt.

BHA was purchased from Sigma (st. Louis. MO.USA). Folin-Cioculteau reagent was obtained fromGerbsaur Chemical Co (Germany). Gallic acid (98\%) was purchased from Aldrich Chemical Co. Ltd., England.

\section{Methods:}

\section{Preparation of ostrich meat nuggets:}

Ostrich meat nuggets were prepared as per the formulation given in Table (1). 
Table (1) : Formulation for ostrich meat nuggets prepared with broccoli powder (Bp) and butylated hydroxyl anisole (BHA)

\begin{tabular}{|c|c|c|c|c|c|c|}
\hline \multirow{2}{*}{ Ingredient (\%) } & \multicolumn{5}{|c|}{ Broccoli powder (\%) } & \multirow{2}{*}{$\begin{array}{c}\text { BHA } \\
\text { nuggets }\end{array}$} \\
\hline & 0 & 2 & 4 & 6 & 8 & \\
\hline Ostrich meat & 72 & 72 & 72 & 72 & 72 & 72 \\
\hline Refined oil & 8.0 & 8.0 & 8.0 & 8.0 & 8.0 & 8.0 \\
\hline Ice flakes & 10.0 & 10.0 & 10.0 & 10.0 & 10.0 & 10.0 \\
\hline Liquid whole & 2.75 & 2.75 & 2.75 & 2.75 & 2.75 & 2.75 \\
\hline egg & & & & & & \\
\hline $\mathrm{NaCL}$ & 1.5 & 1.5 & 1.5 & 1.5 & 1.5 & 1.5 \\
\hline Condiments & 4.0 & 4.0 & 4.0 & 4.0 & 4.0 & 4.0 \\
\hline Spice mix & 2.0 & 2.0 & 2.0 & 2.0 & 2.0 & 2.0 \\
\hline $\begin{array}{l}\text { Refined wheat } \\
\text { flour }\end{array}$ & 2.5 & 2.5 & 2.5 & 2.5 & 2.5 & 2.5 \\
\hline $\begin{array}{l}\text { Broccoli } \\
\text { powder }\end{array}$ & - & 2.0 & 4.0 & 6.0 & 8.0 & - \\
\hline $\mathrm{BHA}(\mathrm{mg} / \mathrm{kg})$ & - & - & - & - & - & 150 \\
\hline
\end{tabular}

Ostrich meat nuggets were prepared according to methods of Banerjee et al. (2012).The deboned frozen ostrich meat nuggets was thawed for $12 \mathrm{~h}$ in refrigerator $\left(4^{\circ} \mathrm{C}\right)$, cut into small chunks and minced twice in a meat mincer (Moulinex) through $6 \mathrm{~mm}$ and $4 \mathrm{~mm}$ plates and then the salt was added and chopped for 2-3 min with simultaneous addition of ice flakes. Refined sunflower oil was slowly incorporated while chopping till it was completely dispered in the batter. Condiment powder (onion and garlic), dry spice mix, refined wheat flour and broccoli powder at different levels $(0,2,4,6,8 \%$ and $\mathrm{BHA}$ treatment) were added, and a control without broccoli powder was included as shown in Table 1. Chopping continued till uniform dispersion of all the ingredients and desired consistency of the emulsion which was prepared in a bowl chopper to make a batter or during which the temperature was maintained below $12^{\circ} \mathrm{C}$. The nuggets obtained was formed by hand and filled in polyethylene bags and the bags were electric sealed before storing at $4^{\circ} \mathrm{C}$ in refrigerator for 15 day.

\section{Analytical methods:}

Raw materials (fresh ostrich meat and dry broccoli powder) and refrigerated samples were evaluated for their proximate composition. Ostrich nuggets samples were evaluated for their chemical composition, physicochemical properties, antioxidant activity as well as sensory evaluation.

\section{Proximate composition :}

Moisture was determined using air oven at $105^{\circ} \mathrm{C}$ until constant weight, crude protein content was estimated using microKjeldahl procedure to determine the total nitrogen and multiply this value by the factor of 6.25 ; ether extract was performed in a Soxhelt apparatus using petroleum ether $\left(40-60^{\circ} \mathrm{C}\right)$ as a solvent and ash content was carried out by subjecting samples to preashing, then complete the ashing in an electric muffle at $550^{\circ} \mathrm{C}$ until constant weight. All of them according to the method described by A.O.A.C. (2005). Total carbohydrates were calculated by difference. Thiobarbituric acid (TBA) as 
$\mathrm{mg}$ malonaldehyde/kg ostrich meat nuggets at zero time and during refrigerated storage at $4^{\circ} \mathrm{C}$ for 15 day was spectrophotometrically determined at $532 \mathrm{~nm}$ using Specteronic JENWAY 6300 spectrophotometer as mentioned by Siu and Draper (1978).

\section{Physicochemical analysis :}

\section{Cooking loss :}

Cooking loss was expressed as $\mathrm{g} / 100 \mathrm{~g}$ and calculated by the weight difference between uncooked and cooked ostrich meat nuggets samples according to Barbanti and Pasquini (2005).

\section{Cooking yield}

The cooking yield of the nugget was determined according to the method of Santhi and Kalaikannan (2014). The value of cooking yield was expressed as percentage following the equation: freshly cooked sample weight at room temperature divided by the uncooked sample weight multiplied by 100 .

$$
\text { Cooking yield }(\%)=\text { cooked weight/uncooked weight } \times 100
$$

\section{Shrinkage :}

Diameter of raw and cooked ostrich nuggets were measured according to the method described by Berry (1993). Percent changes in diameter of sample were calculated as follows :

Diameter reduction $(\%)=$ Fresh diameter - Cooked diameter $/$ Fresh diameter $\times 100$

\section{pH measurement :}

$\mathrm{pH}$ of ostrich meat nuggets was measured using Digital pH-meter ( JENWAY model 333 Research $\mathrm{pH}$ meter) after blending $15 \mathrm{~g}$ ostrich meat nuggets with 150 $\mathrm{ml}$ deionized water for 2 min (Xiong et al. 1993).

\section{Preparation of sample extracts :}

Broccoli powder and ostrich nuggets extracts were obtained by extraction of samples with methanol. The samples $(50 \mathrm{~g})$ were crushed and then extracted three times with $200 \mathrm{ml}$ of the solvent by stirring for $4 \mathrm{~h}$ at $40^{\circ} \mathrm{C}$. After filtration through a folder filter, the supernatants were joined and concentrated under reduced pressure using a rotary evaporator until dryness (Rabaneda et al. 2003).

\section{Determination of antioxidant compounds :}

\section{Total phenolic content :}

The total phenolic content (TPC) in broccoli powder and ostrich nuggets was estimated in the extract following the Folin-Ciocalteu method (Singleton and Rossi, 1965) and Heimler et al. (2005). The reaction mixture was composed of $0.1 \mathrm{ml}$ extract, $7.9 \mathrm{ml}$ distilled water, $0.5 \mathrm{ml}$ of Folin-Ciocalteu's reagent and $1.5 \mathrm{ml}$ of a $20 \%$ sodium carbonate anhydrous solution (added 2 min after the Folin-Ciocalteu's reagent). After initial mixing the opaque flasks were allowed to stand for $2 \mathrm{hrs}$. The O.D of the blue coloured samples was measured spectrophotometrically (JENWAY 6300 ) at $720 \mathrm{~nm}$ and determined as gallic acid equivalents (GAE) and the values were expressed as mg of gallic acid / $\mathrm{g}$ of sample.

\section{Total flavonoids :}

Total flavonoids were analyzed according to the method described by Zhishen et al. (1999). The samples absorbance was measured at $510 \mathrm{~nm}$ on a spectrophotometer (JENWAY 6300) against the blank (distilled water) and catechol was used as standard reagent. The total flavonoids content was expressed as $\mathrm{mg}$ $/ 100 \mathrm{~g}$ (dry weight basis). 


\section{Glucosinolates :}

Glucosinolates content was determined in broccoli powder as allyl isothiocyanate ( $\mathrm{mg} / 100 \mathrm{~g}$ dry weight basis) by using titratable method as the procedure described the standard methods of A.O.A.C. (2000).

\section{Antioxidant activity :}

\section{DPPH radical scavenging activity:}

The ability to scavenge 1, 1-diphenyl-2-picrylhydrazyl (DPPH) radical by added antioxidants in the product was estimated by the method of Kato et al. (1988) with slight modifications. Fresh DPPH solution was prepared in ethanol before every measurement. In this method, about $5 \mathrm{~g}$ of sample was triturated with $20 \mathrm{ml}$ of ethanol for $2 \mathrm{~min}$. The contents were quantitatively transferred into a beaker and filtered through Whatman filter paper No 42. Then, $1 \mathrm{ml}$ of the filtrate was mixed with $1 \mathrm{ml}$ of $0.1 \mathrm{M}$ Tris- $\mathrm{HCl}$ buffer $(\mathrm{pH} 7.4)$ and $1 \mathrm{ml}$ of DPPH reagent $(250 \mu \mathrm{M})$ in test tubes. The content was gently mixed and then the absorbance in time, $\mathrm{t}=0 \mathrm{~min}$ (t0) was measured at $517 \mathrm{~nm}$ using a spectrophotometer (JENWAY 6300). The sample tubes were also incubated at room temperature $\left(27 \pm 1^{\circ} \mathrm{C}\right)$ under dark for measurement of absorbance in time $\mathrm{t}=20 \mathrm{~min}$ ( $\mathrm{t} 20$ ). Ethanol was used as blank sample. Gallic acid $(200-600 \mu \mathrm{M} / \mathrm{ml})$ was used as a standard. The free radical scavenging activity was calculated as a decrease of absorbance from the equation:

Radical scavenging activity $(\%)=100-($ At20 / At0) $\times 100$

\section{ABTS radical scavenging activity:}

The spectrophotometric analysis of 2,2- azino-bis (3-ethylbenzothiazline-6sulphonic) ( $A B T S_{+}$) radical scavenging activity was estimated according to method of Shirwaikar et al. (2006). This method is based on the ability of antioxidants to quench the longlived ABTS+ radical cation, a blue/green chromophore with characteristic absorption at $734 \mathrm{~nm}$, in comparison to that of standard antioxidants. The ABTS was dissolved in water to a $7 \mathrm{mM}$ concentration and potassium persulphate added to a concentration of $2.45 \mathrm{mM}$. The reaction mixture was left to stand at room temperature overnight (12-16 h) in dark to allow the completion of radical generation. Prior to use, the stock solution was diluted with ethanol to an absorbance of 0.70 at t0 ( $t=0 \mathrm{~min})$ and equilibrated at $3^{\circ} \mathrm{C}$ exactly 6 min after initial mixing. About $4.9 \mathrm{ml}$ of ABTS working standard solution was mixed with $100 \mu \mathrm{l}$ of sample extract/standard and absorbance was measured after $20 \mathrm{~min}$ (t20) at $734 \mathrm{~nm}$. Gallic acid (50- $400 \mu \mathrm{M} / \mathrm{ml}$ ) was used as a standard antioxidant. The ABTS+ activity was calculated by using following formula:

ABTS activity $(\%)=[($ At0- At20)/At0 $] \times 100$.

Increased absorbance of the reaction mixture indicated higher reducing power of the sample extract.

\section{Ferric reducing antioxidant power assay :}

Ferric reducing antioxidant power of the extracts was determined according to the method of Oyaizu (1986). Different concentrations of broccoli powder, ostrich nuggets which contained broccoli powder extracts and BHA nuggets were mixed with $2.5 \mathrm{ml}$ of phosphate buffer $(0.2 \mathrm{M}$, pH 6.6) and $2.5 \mathrm{ml}$ of $1 \%(\mathrm{w} / \mathrm{v})$ potassium ferricyanide in $10 \mathrm{ml}$ test tubes. The mixtures were incubated for 20 min at $50{ }^{\circ} \mathrm{C}$ followed by addition of $2.5 \mathrm{ml}$ of $10 \%$ trichloroacetic acid and then centrifugation at $6000 \mathrm{rpm}$ for $10 \mathrm{~min}$. The supernatant $(2.5 \mathrm{ml})$ was mixed with $2.5 \mathrm{ml}$ distilled water and $0.5 \mathrm{ml}$ of ferric chloride $(0.1 \% \mathrm{w} / \mathrm{v})$, and the absorbance was measured 
at $700 \mathrm{~nm}$ (Hitachi, U-28000 Spectrophotometer, Tokyo, Japan). Increase in absorbance of the reaction mixture indicated the reducing power of the sample.

\section{Sensory evaluation :}

Ostrich meat nuggets were prepared by deep frying in sunflower oil for $3 \mathrm{~min}$ to every side befor sensory evalution and coded nuggets samples were served at room temperature. Colour, flavor, taste, juiceness, texture, overall acceptability of ostrich meat nuggets were subjectively evaluated using 10 panalist of Food Science and Technology Department, Faculty of Home Economic , Al-Azhar univ., Egypt. Hedonic ranking test where $9=$ extremely acceptable to $1=$ =xtremely rejected as described by Kramer and Twigg (1970).

\section{Statistical analysis :}

The analyses were carried out in three replicates for all determinations. The means and standard deviation of way analysis of variance (ANOVA). A multiple comparison procedure of the treatment means was performed by Duncan's New Multiple Rang Test. Significance of the differences was defined as $p<0.05$ (SPSS, 1997).

\section{RESULTS AND DISCUSSION}

\section{Proximate analysis of ostrich meat and broccoli powder (Bp) :}

The results of the chemical composition of ostrich meat and broccoli are presented in Table (2). The moisture, protein, ether extract and ash contents in the ostrich meat and broccoli were found to be (on wet weight basis) 72.97 and $87.41 \%, 24.83$ and $3.08 \%, 0.74$ and $0.56 \%$ and 1.38 and $1.26 \%$ respectively. Whereas, on dry weight basis, the values reached to 91.86 and $22.43 \% ; 2.74$ and $4.09 \% ; 4.994$ and $9.223 \%$ respectively. The results indicated that ostrich meat had low fat content $(0.74 \%)$ and high protein content $(24.83 \%)$ based on wet weight. These data were in the range reported in a previous study (Abou-Arab and Abu-Salem, 2010) which concluded the range of moisture, protein, lipid and ash in ostrich meat were $75 \%, 22.4 \%, 1.5 \%$ and $1.1 \%$, respectively. Olga et al. (2009) revealed the chemical composition of broccoli floret and leaf flours i.e. $22.41 \mathrm{~g}$ and $12.31 \mathrm{~g}$ protein, $7.87 \mathrm{~g}$ and $14.67 \mathrm{~g}$ ash, 4.59 and $6.72 \mathrm{~g}$ fat, 11.65 and $12.83 \mathrm{~g}$ crude fiber and $65.13 \mathrm{~g}$ and $66.48 \mathrm{~g}$ of carbohydrates. Also, Alsuhaibani (2013) reported that protein, fat, fiber moisture ash and carbohydrate were $25.21,3.25,12.77,7.31,10.11$ and $41.35 \%$ respectively in broccoli powder.

Table (2): Proximate analysis of ostrich meat and broccoli powder

\begin{tabular}{lcccc}
\hline Constituent & \multicolumn{2}{c}{ Ostrich meat , \% } & \multicolumn{2}{c}{ Broccoli powder , \% } \\
\cline { 2 - 5 } & W.W & D.W & W.W & D.W \\
\hline Moisture & 72.97 & - & 87.41 & 8.13 \\
Crude protein & 24.83 & 91.86 & 3.08 & 22.43 \\
Ether extract & 0.74 & 2.74 & 0.56 & 4.09 \\
Ash & 1.38 & 4.994 & 1.26 & 9.223 \\
Crude fiber & - & - & 1.88 & 13.68 \\
${ }^{*}$ Carbohydrates & 73.05 & 0.41 & 93.22 & 50.58 \\
\hline * Carbohydrates were calculated by difference & & \\
$\quad$ Values are means of three replicates & &
\end{tabular}




\section{Antioxidant compounds in broccoli powder :}

Phenolic compounds are secondary metabolites that can neutralize or quench free radicals (Picchi et al. 2012). Data in Table (3) show that broccoli powder have a considerable amount of total polyphenols $17.955 \mathrm{mg} / \mathrm{g}$, these result confirmed possibility of using broocoli powder as antioxidant source in food processing. Flavonoids or bioflavonoids are unique low molecular weight ubiquitous polyphenolic compounds produced by plants during their metabolic activities as a secondary metabolites and responsible for major organoleptic characteristics and health benefits of plant derived foods (Kumar et al. 2013). The value of total flavonoid reached to $56.56 \mathrm{mg} / \mathrm{g}$ as shown in Table (3) . In accordance, Borowski et al. (2008) reported that brocooli had high value of total phenol and flavonoids as the value were 87.38 and $19.96 \mathrm{mg} / 100 \mathrm{~g}$ respectively

Glucosinolates constitute a major group of natural plant compounds in the family Brassicaceae. They are responsible for the hot and pungent flavor of crucifers and exhibit anticancer activity (Fahey et al. 2001). From the obtained data (Table,3 ), it could be noticed that glucosinolates was represented about $9.15 \mathrm{mg} / \mathrm{g}$ as allyl isothiocyanate. The broccoli powder was found to possess good antioxidant activity, these results indicate capability to use broccoli powder as natural antioxidant in food processing. From the tabulated data (Table, 3), it could be noticed that antioxidant activity of broccoli powder which measured by DPPH , ABTS (both free nradical scavenging assays) and reducing power was $75.831 \%, 68.45 \%$ and 0.88 (absorbance), respectively. The reducing power of a compound is related to its electron-transfer ability; therefore, the reducing capacity of a compound may serve as a significant indicator of its potential antioxidant activity (Banerjee et al. 2012). Polyphenols are chemical compounds being secondary plant metabolites. They constitute the most abundant group of natural antioxidants, which can neutralize or quench free radicals (Rosicka-Kaczmarek, 2004, Picchi et al. 2012) Flavonoids and their derivatives are the largest group of plant polyphenols (Hounsome et al. 2009). They possess strong antioxidant activity due to their ability to scavenge reactive oxygen species and inhibit oxidative stress (Pourcel et al. 2007).

Table (3) : Total phenolic compounds, flavonoids, glucosinolates* and antioxidant activity of broccoli powder

\begin{tabular}{|c|c|}
\hline Antioxidant compounds & Value ** \\
\hline Total phenolic $\quad(\mathrm{mg} / \mathrm{g})$ & $17.955 \pm 1.66$ \\
\hline Total flavonoids $\quad(\mathrm{mg} / \mathrm{g})$ & $56.56 \pm 2.08$ \\
\hline Glucosinolates * $(\mathrm{mg} / \mathrm{g})$ & $9.15 \pm 1.37$ \\
\hline $\begin{array}{l}\text { Antioxidant activity: } \\
\text { DPPH \% } \\
\text { ABTS \% } \\
\text { Reducing power }\end{array}$ & $\begin{array}{c}75.831 \pm 0.33 \\
68.45 \pm .81 \\
0.88 \pm .26\end{array}$ \\
\hline
\end{tabular}




\section{Influence of broccoli powder (BP) on chemical composition of ostrich meat nuggets :}

The chemical composition of fresh ostrich meat nuggets as affected by addition of different levels of broccoli powder is presented in Table (4).

It could be noticed that the chemical composition of ostrich meat nuggets was affected by the addition of broccoli powder. The moisture content in ostrich meat nuggets samples was in the range of $63.73 \%$ to $66.62 \%$. The moisture content was decreased with the increase in level of incorporation of broccoli powder in the product. This might be due to hygroscopic nature of the broccoli powder (Kumar et al. 2013). Similar findings were also reported by many researchers on addition of different powders and fat replacers (Kumar and Sharma, 2004 ; Mendiratta et al. 2013). The protein and fat contents of the control (with or without synthetic antioxidant, BHA) were significantly $(P<0.05)$ higher than treatments. These results are in agreement with those reported by Kumar et al. (2013) who found that protein and fat content of emu meat nuggets were decreased as broccoli powder in emu nuggets increased in their formula.

The data in the same Table (4) shows that the ash and crude fiber of ostrich meat nuggets were significantly increased as the amounts of BP in its formula increased. This may be due to the property of broccoli powder, since it contains high crude fiber, ash and carbohydrate but low in protein comparing with ostrich meat. These results are in the line with those reported by Kumar et al. (2013).

As shown in Table (4), TBA value of ostrich meat nuggets was significantly $(p<0.05)$ affected by presence of broccoli powder in its formula. TBA value of control ostrich nuggets was $1.39 \mathrm{mg}$ malonaldehyde / Kg sample significantly ( $\mathrm{p}$ $<0.05$ ) decreased to 0.89 in nuggets contains $8 \%$ broccoli powder. This may be due to presence of some polyphenolic compounds ,flavonoids and glucosinolates in broccoli powder which have an antioxidant activity to inhibit TBA formation. The highest TBA value of the control sample might be due to an interaction between the natural substances (for example, polyunsaturated fatty acids) and catalysts (for example, iron ion) from the meat tissue (Kim et al., 2000). So, mixing minced ostrich meat with various levels of broccoli powder caused a significant reduction of TBA values compared to control samples.

Table (4): Proximate chemical composition of ostrich meat nuggets as affected by addition of broccoli powder

\begin{tabular}{|c|c|c|c|c|c|c|}
\hline \multirow{2}{*}{$\begin{array}{c}\text { Components } \\
(\%)\end{array}$} & \multicolumn{5}{|c|}{ Ostrich nuggets containing broccoli powder } & \multirow{2}{*}{$\begin{array}{c}\text { Nuggets } \\
\text { (with BHA) }\end{array}$} \\
\hline & $\%$ & $\%$ & $\%$ & $6 \%$ & $8 \%$ & \\
\hline Moisture & $66.45 \pm .487^{\mathrm{ab}}$ & $65.72 \pm .278^{\mathrm{ab}}$ & $05.51 \pm .309$ & $04.04 \pm .<0 /$ & $63.73 \pm .984^{\mathrm{c}}$ & $66.62 \pm .264^{\mathrm{a}}$ \\
\hline protein & $20.13 \pm .13^{\mathrm{a}}$ & $17.87 \pm .008^{\mathrm{b}}$ & $17.84 \pm .004^{\mathrm{b}}$ & $17.43 \pm .149^{\mathrm{C}}$ & $17.31 \pm .31^{\mathrm{C}}$ & $20.09 \pm .003^{\mathrm{a}}$ \\
\hline lipids & $8.78 \pm .12^{\mathrm{a}}$ & $8.48 \pm .28^{\mathrm{a}}$ & $7.92 \pm .002^{b}$ & $7.57 \pm .007^{\mathrm{c}}$ & $7.33 \pm .33^{\mathrm{c}}$ & $8.66 \pm .104^{\mathrm{a}}$ \\
\hline As & $3.56 \pm .003^{\mathrm{ab}}$ & $3.72 \pm .208^{\mathrm{ab}}$ & $3.83 \pm .335^{\mathrm{ab}}$ & $3.88 \pm .1$ & $4.06 \pm .544^{\mathrm{a}}$ & $3.45 \pm .421^{b}$ \\
\hline Fiber & $0.84 \pm .004^{\mathrm{e}}$ & $1.43 \pm .001^{d}$ & $1.97 \pm .420^{\mathrm{C}}$ & $2.399 \pm .005^{\mathrm{b}}$ & $3.23 \pm .003^{\mathrm{a}}$ & $0.72 \pm .006^{\mathrm{e}}$ \\
\hline TBA * & $1.39 \pm .0119^{\mathrm{a}}$ & $1.24 \pm .02739^{b}$ & $1.27 \pm .0191^{\mathrm{b}}$ & $0.91 \pm .04435^{d}$ & $0.89 \pm .02383 d$ & $0.96 \pm .0156^{\mathrm{c}}$ \\
\hline
\end{tabular}

Mean \pm Standard Deviation of three values 
In a row, values have the same superscript letters are not significantly different by Dancen's Test at $5 \%$ level

* mg malonaldehyde / kg sample

TBA value of raw ostrich meat $=0.98 \mathrm{mg}$ malonaldehyde $/ \mathrm{kg}$

\section{Influence of broccoli powder on physicochemical properties of ostrich meat nuggets :}

The $\mathrm{pH}$, cooking loss, cooking yield and shrinkage of control, ostrich nuggets prepared with broccoli powder and BHA is presented in Table (5). $\mathrm{pH}$ value of fresh ostrich nuggets and BHA treatment was 6.28 (control), and 6.22 (control with BHA) significantly $(p<0.05)$ decreased to 6.21, 5.734, 5.451 and 5.33 in ostrich meat nuggets contained 2, 4, 6 and $8 \%$ broccoli powder respectively. The lower $\mathrm{pH}$ could be attributed to the relative increase in the concentration of organic acid in brocooli powder. Similar results were obtained by Banerjee et al. (2012) who found that higher amount of broccoli powder extract significantly decreased the $\mathrm{pH}$ value of goat meat nuggets.

Table (5) reveals that cooking loss of ostrich meat nuggets was gradually decreased contrary to cooking yield which was significantly $(p<0.05)$ increase by rose the percentage of added of broccoli powder. The lowest cooking loss $(6.813 \%)$ was observed in ostrich nuggets contained $8 \%$ broccoli powder, in the meantime it had the significantly $(\mathrm{p}<0.05)$ highest cooking yield $(93.187 \%)$.

Cooking yield was significantly $(p<0.05)$ higher for ostrich meat nuggets incorporated with broccoli powder than other treatments as well as control and $\mathrm{BHA}$ treatment. The increase in the cooking yield might be due to higher water retention properties of the fiber in broccoli powder. These results are in agreement with those reported by Garcia et al. (2002) who reported an increase in cooking yield and moisture retention in dry fermented sausage upon incorporation of fruit fiber and cereals. Mehta et al. (2013) and Mendiratta et al. ( 2013) also reported an increase in cooking yield of meat products on incorporation of fruit and vegetables fibers.

Table (5) shows that shrinkage (\%) of ostrich meat nuggets significantly $(p<$ 0.05 ) decreasd as the broccoli powder increased. For instance, shrinkage of control samples (with or without BHA) was 12.43 and $11.88 \%$, respectively, which was markedely decreased to reash $5.48 \%$ for nuggets contained $8 \%$ broccoli powder. The depression in shrinkage of nuggets may be explained by the ability of broccoli powder to bind fat and to retain moisture. These results are in agreement with those reported by Bennion and Scheule (2004) who stated that Shrinkage of cooked meat was attributed to shortening of muscle fibers, coagulation of protein, loss of water and melting fat during frying. 
Table (5): Some physical properties of ostrich meat nuggets as affected by addition of broccoli powder at different levels

\begin{tabular}{lllll}
\hline \multicolumn{1}{c}{ Sample } & \multicolumn{1}{c}{$\mathbf{p H}$} & $\begin{array}{c}\text { Cooking loss } \\
\%\end{array}$ & $\begin{array}{c}\text { Cooking yield } \\
\%\end{array}$ & $\begin{array}{c}\text { Shrinkage } \\
\%\end{array}$ \\
\hline Control & $6.28 \pm . .06^{\mathrm{a}}$ & $17.09 \pm .100^{+\mathrm{a}}$ & $82.91 \pm .36^{\mathrm{e}}$ & $12.43 \pm .120^{\mathrm{a}}$ \\
$\mathrm{Bp} \%$ & $6.21 \pm .21^{\mathrm{a}}$ & $11.23 \pm .003^{\mathrm{b}}$ & $88.776 .008^{\mathrm{c}}$ & $11.96 \pm .008^{\mathrm{b}}$ \\
$\mathrm{Bp} 4 \%$ & $5.734 \pm .13^{\mathrm{b}}$ & $8.28 \pm .28^{\mathrm{c}}$ & $91.717 \pm .70^{\mathrm{b}}$ & $10.49 \pm .500^{\mathrm{c}}$ \\
$\mathrm{Bp} \mathrm{6 \%}$ & $5.451 \pm .05^{\mathrm{c}}$ & $8.01 \pm .46^{\mathrm{c}}$ & $91.99 \pm .001^{\mathrm{b}}$ & $7.14 \pm .140^{\mathrm{d}}$ \\
$\mathrm{Bp} 8 \%$ & $5.33 \pm .200^{\mathrm{c}}$ & $6.813 \pm .31^{\mathrm{d}}$ & $93.187 \pm .42^{\mathrm{a}}$ & $5.38 \pm .003 \mathrm{e}$ \\
BHA $(150 \mathrm{mg} / \mathrm{kg})$ & $6.22 \pm .028_{\mathrm{a}}$ & $12.68 \pm .14^{\mathrm{a}}$ & $87.315 \pm .32^{\mathrm{d}}$ & $11.88 \pm .002^{\mathrm{b}}$ \\
\hline
\end{tabular}

Mean \pm Standard Deviation of three values

In a colum, values have the same superscript letters are not significantly different by Dancen's

Test at $5 \%$ level

Bp 2\% = ostrich nuggets with $2 \%$ broccoli powder

Bp 4\% = ostrich nuggets with $4 \%$ broccoli powder

Bp $6 \%=$ ostrich nuggets wih $6 \%$ broccoli powder

Bp 8\% = ostrich nuggets with $8 \%$ broccoli powder

BHA = ostrich nuggets with butylated hydroxyl anisol $(150 \mathrm{mg} / \mathrm{kg})$

\section{Antioxidant activity :}

The DPPH radical has been widely used to test the free radical scavenging ability of various natural products and has been accepted as a model compound for free radicals originating in lipids (Da Porto et al. 2000). The DPPH method used in this study to estimate antioxidant activity is based on the ability of antioxidants to reduce the DPPH free radical. DPPH free radical scavenging activity of ostrich meat nuggets incorporated with broccoli powder, control and $\mathrm{BHA}$ nuggets are shown in Table (6). The results showed that ostrich meat nuggets incorporated $8 \%$ broccoli powder had the highest DPPH, ABTS and reducing power comparing with another treatment or BHA nuggets. The percent radical scavenging activity of broccoli powder incorporated ostrich nuggets was increased significantly $(p<0.05)$ with the increase in the levels of incorporation, it did show proton donating ability and could serve as free radical inhibitors or scavengers that can be used as antioxidants. Banerjee et al. (2012) reported the DPPH radical scavenging activity of $2.25 \mathrm{mg}$ and $3 \mathrm{mg}$ broccoli powder was comparable to the activity of 50 and $100 \mathrm{ppm}$ BHT, respectively. Kim et al. (2013) also reported the radical scavenging activity of broccoli powder. The efficacies of antioxidants are often associated with their ability to scavenge stable free radicals of DPPH by donating electron to the unpaired valence electron at one atom of nitrogen bridge (Sreelatha and Padma, 2009; Krishnaraju et al. 2009). The DPPH free radical scavenging by antioxidants is due to their hydrogen donating ability; the more the number of hydroxyl groups, the higher the possibility of free radical scavenging ability (Chen and Ho, 1995). Broccoli powder and extract are rich source of various phenolic compounds (Kim et al. 2013) and thus can be incorporated into meat products as a source of natural antioxidants to prolong quality and stability. 


\section{ABTS assay :}

All addition of broccoli powder showed effective scavenging activity against ABTS radical as shown in Table (6). Ostrich meat nuggets contained $8 \%$ broccoli powder produced the highest percentage inhibition comparing with another treatment or BHA nuggets. Also, ABTS scavenging activity showed increased significantly $(p<0.05)$ with the increasing levels of broccoli powder incorporation of ostrich meat nuggets. It has been observed that all the treated samples exhibited significantly $(p<0.05)$ higher ABTS scavenging activity than control (Table, 6 ). The high inhibitory percentage in ostrich nuggets contained broccoli powder could be attributed to the presence of flavonoids and polyphenolic compounds in broccoli powder. Even though DPPH and ABTS are both radical scavenging assays, percentage inhibition will vary due to different methods of preparation (Qwele, 2011). The DPPH radical is stable at formation whereas the ABTS assay allows formation of a radical which remains stable for several days due to the optimized $\mathrm{pH}$ (Cano et al. 1998), hence lower antioxidant scavenging activity.

\section{Ferric reducing antioxidant power:}

Table (6) shows the reducing power of ostrich nuggets with broccoli powder and BHA. The reducing powder of ostrich meat nuggets was influenced by addition of broccoli powder in its formula. Since reducing power of ostrich nuggets increased as the broccoli powder incorporate in its formula.

For instance, reducing power of ostrich nuggets free from brocooli powder (control) was 0.43 significantly $(p<0.05)$ increased to $0.66,0.73,0.78,0.89$ for samples contained $2 \%, 4 \%, 6 \%$ and $8 \%$, whereas was 0.63 in $\mathrm{BHA}$ (100 ppm) nuggets. Higher absorbance exhibited in ostrich nuggets contained $8 \%$ broccoli powder is due to the high polyphenolic content in broccoli powder. Additionally, it has been reported that the reducing power of bioactive compounds is directly related to its antioxidant activity (Iqbal and Bhanger, 2006). Amarowicz et al. (2004) observed a direct correlation between antioxidant activities and reducing power of certain plant extracts, which have been shown to exert antioxidant action by breaking the free radical chain through donation of hydrogen atom.

The results indicate that broccoli powder provoke noticeable scavenging on free radicals and enhance the stability against primary oxidation. The presence of antioxidants in meat causes the reduction of $\mathrm{Fe}^{3+} /$ ferric cyanide complex to the ferrous form ( $\mathrm{Fe}^{2+}$ ) (Chung et al. 2002). Broccoli had strong antioxidant activities due to their contents of total polyphenol, flavonoid and glucosinolates, which exhibited an ability to scavenge reactive oxygen species, metal chelators and inhibit oxidative stress (Pourcel et al. 2007; Charoensiri et al. 2009 ) . High contents of antioxidants may be found in fruits and vegetables as well as in their processed products. Their action is chiefly based on the neutralization of free radicals and on the prevention from oxidation processes (Sikora et al. 2008). 
Table (6): Antioxidant potential of ostrich nuggets incorporated with different levels of broccoli powder

\begin{tabular}{|c|c|c|c|}
\hline \multirow[t]{2}{*}{ Sample } & \multicolumn{3}{|c|}{ Antioxidant potential } \\
\hline & DPPH \% & ABTS \% & Reducing power \\
\hline Control & $53.66 \pm 0.66^{c}$ & $35.22 \pm 0.220^{\dagger}$ & $0.43 \pm 0.002^{\mathrm{e}}$ \\
\hline Вp 2\% & $56.87 \pm 0.43^{b}$ & $45.14 \pm 0.14^{\mathrm{e}}$ & $0.66 \pm 0.001^{d}$ \\
\hline Вp 4\% & $57.47 \pm 0.47^{b}$ & $48.08 \pm 0.008^{d}$ & $0.73 \pm 0.003^{c}$ \\
\hline Вp 6\% & $62.95 \pm 1.948^{\mathrm{a}}$ & $51.295 \pm 0.003^{b}$ & $0.78 \pm 0.010^{b}$ \\
\hline Вp 8\% & $63.01 \pm 1.010^{\mathrm{a}}$ & $53.70 \pm 0.3859^{a}$ & $0.89 \pm 0.100^{\mathrm{a}}$ \\
\hline BHA (150 mg / kg) & $62.129 \pm 0.130^{\mathrm{a}}$ & $50.75 \pm 0.1762^{c}$ & $0.63 \pm 0.003^{d}$ \\
\hline
\end{tabular}

Mean \pm Standard deviation of three values

In a column, values have the same superscript letters are not significantly different by Dancen's test at $5 \%$ level

Bp $2 \%=$ ostrich nuggets with $2 \%$ broccoli powder

Bp $4 \%=$ ostrich nuggets with $4 \%$ broccoli powder

Bp $6 \%=$ ostrich nuggets wih $6 \%$ broccoli powder

Bp $8 \%=$ ostrich nuggets with $8 \%$ broccoli powder

BHA = ostrich nuggets with butylated hydroxyl anisole $(150 \mathrm{mg} / \mathrm{kg})$

Therefore, the importance of replacing synthetic antioxidants with natural ingredients from broccoli powder has greatly increased.

Influence of added broccoli powder on organolyptic properties of ostrich meat nuggets :

Sensory characteristics of ostrich meat nuggets as affected by adding different levels of broccoli powder and BHA $(150 \mathrm{mg} / \mathrm{kg})$ are presented in Table (7). No significant $(p<0.05)$ differences were observed in color, firmness, texture and juiciness between samples mixed with 2, 4, 6 and $8 \%$ broccoli powder to those mixed with BHA or control (without any addition) and the panelists did not detected differences between control ostrich meat nuggets and samples contained broccoli powder in previous sensory quality criteria. These results are in agreement with those reported by Banerjee et al. (2012) who reported a non significant difference in the organoleptic characteristics of control and broccoli powder extract and BHT incorporated goat meat nuggets. From the obtained data (Table,7 ), it could be exhibited that there was significant $(p<0.05)$ difference between the control ostrich nuggets and those added with broccoli powder with regard to flavor, taste and overall acceptability. As seen from the results, panelists accepted the determined organoleptic properties of ostrich nuggets free or containing preserving agent or broccoli powder, all samples showed good overall acceptability; in all cases the values were higher than 8.0. So, the results of sensory evaluation suggest that the broccoli powder phenolic compounds can be successfully used as natural antioxidant without adversely affecting sensory characteristics of ostrich meat nuggets. Kumar et al. (2013) reported that nuggets with higher level of incorporation of broccoli powder showed a significant decreasing trend for color and appearance, flavor, tenderness juiciness and overall acceptability.

The data in the same Table $(7)$ shows that the significantly $(p<0.05)$ highest mean panelist's flavor value of ostrich meat nuggets (9.40) was detected for sample contained $2 \%$ broccoli powder. On the hand, the significantly $(p<0.05)$ 
lowest one (7.40) was observed for samples contained $8 \%$ broccoli powder (Table 7 ). This may be due to broccoli powder had a special flavor which affected on the flavor and taste of the final product. Mendiratta et al. (2013) reported that vegetable incorporated mutton nuggets was successfully improved the functional and sensory quality.

Table (7): Sensory attributes (at Zero time) of ostrich meat nuggets as affected by addition of broccoli powder at different levels

\begin{tabular}{lccccccc}
\hline Sample & $\begin{array}{c}\text { Color } \\
(10)\end{array}$ & $\begin{array}{c}\text { Firmness } \\
(10)\end{array}$ & $\begin{array}{c}\text { Flavor } \\
(10)\end{array}$ & $\begin{array}{c}\text { Taste } \\
(10)\end{array}$ & $\begin{array}{c}\text { Texture } \\
(10)\end{array}$ & $\begin{array}{c}\text { Juiciness } \\
(10)\end{array}$ & $\begin{array}{c}\text { Overall } \\
\text { acceptability }\end{array}$ \\
& & & & & & $(10)$ \\
\hline Control & $9.60 \pm .5477^{\mathrm{a}}$ & $9.60 \pm .8944^{\mathrm{a}}$ & $9.20 \pm .4472^{\mathrm{a}}$ & $9.40 \pm .5477^{\mathrm{a}}$ & $9.40 \pm .8944^{\mathrm{a}}$ & $9.20 \pm .8367^{\mathrm{a}}$ & $9.50 \pm .500^{\mathrm{a}}$ \\
$\mathrm{Bp} \mathrm{2 \%}$ & $9.60 \pm .8944^{\mathrm{a}}$ & $9.00 \pm 1.2247^{\mathrm{a}}$ & $9.40 \pm .8944^{\mathrm{a}}$ & $8.80 \pm .8367^{\mathrm{ab}}$ & $8.60 \pm 1.1402^{\mathrm{a}}$ & $8.80 \pm .8367^{\mathrm{a}}$ & $9.20 \pm .8367^{\mathrm{a}}$ \\
$\mathrm{Bp} \mathrm{4 \%}$ & $9.80 \pm .4472^{\mathrm{a}}$ & $9.00 \pm 12247^{\mathrm{a}}$ & $8.40 \pm 1.1402^{\mathrm{ab}}$ & $8.40 \pm .9844^{\mathrm{abc}}$ & $9.40 \pm .8944^{\mathrm{a}}$ & $9.20 \pm .8367^{\mathrm{a}}$ & $9.00 \pm .7071^{\mathrm{ab}}$ \\
$\mathrm{Bp} 6 \%$ & $9.20 \pm .8367^{\mathrm{a}}$ & $9.60 \pm .5477^{\mathrm{a}}$ & $8.40 \pm 1.1402^{\mathrm{ab}}$ & $7.60 \pm 1.3416^{\mathrm{bc}}$ & $8.80 \pm .8367^{\mathrm{a}}$ & $8.40 \pm .5477^{\mathrm{a}}$ & $8.50 \pm .500 \mathrm{a}^{\mathrm{b}}$ \\
$\mathrm{Bp} \mathrm{8 \%}$ & $8.40 \pm 1.1402^{\mathrm{a}}$ & $9.20 \pm 1.0954^{\mathrm{a}}$ & $7.40 \pm 1.1402^{\mathrm{b}}$ & $7.20 \pm 1.0954^{\mathrm{c}}$ & $8.40 \pm .8944^{\mathrm{a}}$ & $8.20 \pm 1.0954^{\mathrm{a}} 8.00 \pm 1.00^{\mathrm{b}}$ \\
$\mathrm{BHA}$ & $9.20 \pm 1.7889^{\mathrm{a}}$ & $9.40 \pm 1.3416^{\mathrm{a}}$ & $8.60 \pm .5477^{\mathrm{ab}}$ & $8.60 \pm 1.1402^{\mathrm{abc}} 9.00 \pm 1.00^{\mathrm{a}}$ & $8.20 \pm .8367^{\mathrm{a}} 8.90 \pm .8944^{\mathrm{ab}}$ \\
\hline F-value & 1.163 & 0.321 & 2.900 & 3.200 & 0.948 & 1.526 & 2.426 \\
\hline
\end{tabular}

Mean \pm Standard deviation of ten values

In a column, values have the same superscript letters are not significantly different at $5 \%$ level

Bp $\mathbf{2 \%}=$ ostrich nuggets with $\mathbf{2} \%$ broccoli powder

Bp 4\% = ostrich nuggets with $4 \%$ broccoli powder

Bp 6\% = ostrich nuggets wih $6 \%$ broccoli powder

Bp 8\% = ostrich nuggets with $8 \%$ broccoli powder

BHA = ostrich nuggets with butylated hydroxyl anisole $(150 \mathrm{mg} / \mathrm{kg})$

\section{Influence of refrigerated storage on chemical properties of ostrich meat nuggets contained broccoli powder :}

As shown in Table (8), moisture content of ostrich nuggets was significantly $(p<0.05)$ decreased as storage period increased. These results are in agreement with those obtained by Rehab (2002) who reported that the decrease in moisture content in sasauge and beef meat during storage might due to the reduction in protein solubility and consequently decrease in water holding capacity. Also, the data indicate that crude protein and crude lipid contents decreased in nugget samples after 15 day of storage at $4^{\circ} \mathrm{C}$. This reduction of protein and lipid may be due to hydrolysis of proteins and triglycerides by microbial enzymes. These results are in the line of Morsi (1988) who reported that the decrease of protein during cold storage could be attributed partially to the breakedown of proteins by protolytic enzymes which are not compeletly inactivated during cold storage as well as the loss of the nitrogenous compounds either as volatile substance caused by microbial effect by analogy. From the tabulated data, it could be noticed that ash content of 
ostrich nuggets incorporated broccoli powder was significantly $(p<0.05)$ decreased as the storage period increased.

Table (8) : Effect of refrigerated storage at $4^{\circ} \mathrm{C}$ for 15 day on chemical properties of ostrich nuggets contained broccoli powder

\begin{tabular}{lcccccc}
\hline \multirow{2}{*}{$\begin{array}{c}\text { Components } \\
(\%)\end{array}$} & \multicolumn{5}{c}{ Ostrich nuggets containing broccoli powder } & Nuggets \\
\cline { 2 - 6 } & $\mathbf{0} \%$ & $\mathbf{2 \%}$ & $\mathbf{4} \%$ & $\mathbf{6 \%}$ & $\mathbf{8 \%}$ & with BHA \\
\hline Moisture & $65.24 \pm .23^{\mathrm{a}}$ & $63.31 \pm .08^{\mathrm{b}}$ & $62.12 \pm .13^{\mathrm{c}}$ & $61.23 \pm .29^{\mathrm{d}}$ & $61.03 \pm .03^{\mathrm{d}}$ & $64.86 \pm .11^{\mathrm{a}}$ \\
Crude protein & $20.00 \pm .06^{\mathrm{a}}$ & $17.25 \pm .11^{\mathrm{b}}$ & $17.14 \pm .23^{\mathrm{b}}$ & $16.87 \pm .09^{\mathrm{c}}$ & $16.56 \pm .13^{\mathrm{c}}$ & $19.54 \pm .16^{\mathrm{d}}$ \\
Crude lipids & $8.24 \pm .19^{\mathrm{a}}$ & $8.16 \pm .25^{\mathrm{a}}$ & $7.32 \pm .19^{\mathrm{b}}$ & $7.13 \pm .39^{\mathrm{c}}$ & $7.09 \pm .18^{\mathrm{c}}$ & $8.27 \pm .13^{\mathrm{a}}$ \\
Ash & $3.09 \pm .09^{\mathrm{a}}$ & $3.32 \pm .18^{\mathrm{b}}$ & $3.64 \pm .21^{\mathrm{c}}$ & $3.72 \pm .09^{\mathrm{c}}$ & $3.89 \pm .21^{\mathrm{d}}$ & $3.16 \pm .14^{\mathrm{b}}$ \\
Fiber & $1.16 \pm .01^{\mathrm{a}}$ & $3.26 \pm .18^{\mathrm{b}}$ & $3.88 \pm .12^{\mathrm{c}}$ & $5.16 \pm .23^{\mathrm{d}}$ & $7.22 \pm .16^{\mathrm{e}}$ & $1.18 \pm .09^{\mathrm{a}}$ \\
\hline
\end{tabular}

Mean \pm Standard Deviation of three values

In a row, values have the same superscript letters are not significantly different by

Dancen's Test at 5\% level

\section{Influence of broccoli powder and BHA on TBA value of ostrich meat nuggets during refrigerated storage :}

Lipid oxidation is the major factor in reducing the quality and acceptability of meat and fat products (Morrissey et al. 1998). The effect of broccoli powder addition to ostrich meat nuggets on lipid oxidation during refrigerated period (15 day at $4^{\circ} \mathrm{C}$ ) was tabulated in Table (9). TBA value of all nuggets increased significantly with the advancement of storage period. The TBA values of control sample increased significantly from 1.39 to $2.11 \mathrm{mg}$ malonaldehyde $/ \mathrm{kg}$ after 15 days of refrigerated storage.The increase in TBA of nuggets contained broccoli powder was lower than that of control sample. This reduction or delaying of lipid oxidation may due to the presence of the phenolic compounds of broccoli powder. Phenoilc compounds have free radical scavenger activity similar to the synthetic antioxidants and may also chelate metal ions, such as $\mathrm{Fe}^{+2}$, result in the reduction of the formation rate of activated oxygen (Podsedek, 2007). However, these values were well below the acceptable limits (except control in the end of refrigerated period which recorded $2.11 \mathrm{mg}$ malonaldehyde / $\mathrm{Kg}$ sample) of $1-2 \mathrm{mg}$ malonaldehyde per kilogram meat (Witte et al. 1970). The difference was found to be non significant $(p<0.05)$ in between ostrich nuggets incorporated 8\% broccoli powder and BHA (150 $\mathrm{mg} / \mathrm{kg}$ ) ostrich nuggets. Our results are in agreement with Banerjee et al.(2012) who reported that goat nuggets incorporated with broccoli powder had significant reduces in lipid peroxidation similar to $100 \mathrm{ppm}$ BHT, thus improving the product quality and stability. 
Table (9): Effect of broccoli powder and BHA on TBA value * of ostrich nuggets during refrigerated storage at $4^{\circ} \mathrm{C}$ for 15 day

\begin{tabular}{lccccc}
\hline \multirow{2}{*}{ Sample } & \multicolumn{5}{c}{ Storage period (days) } \\
\cline { 2 - 6 } & \multicolumn{1}{c}{$\mathbf{0}$} & $\mathbf{4}$ & $\mathbf{8}$ & $\mathbf{1 2}$ & $\mathbf{1 5}$ \\
\hline Control & $1.39 \pm .009^{\mathrm{a}}$ & $1.42 \pm .002^{\mathrm{a}}$ & $1.52 \pm .002^{\mathrm{a}}$ & $1.87 \pm .001^{\mathrm{a}}$ & $2.11 \pm .11^{\mathrm{a}}$ \\
$2 \% \mathrm{Bp}$ & $1.24 \pm .004^{\mathrm{b}}$ & $1.28 \pm .003^{\mathrm{b}}$ & $1.33 \pm .003^{\mathrm{b}}$ & $1.39 \pm .001^{\mathrm{b}}$ & $1.66 \pm .006^{\mathrm{b}}$ \\
$4 \% \mathrm{Bp}$ & $1.27 \pm .002^{\mathrm{b}}$ & $1.29 \pm .001^{\mathrm{b}}$ & $1.37 \pm .002^{\mathrm{b}}$ & $1.42 \pm .002^{\mathrm{b}}$ & $1.53 \pm .003^{\mathrm{c}}$ \\
$6 \% \mathrm{Bp}$ & $0.91 \pm .002^{\mathrm{c}}$ & $1.12 \pm .002^{\mathrm{c}}$ & $1.23 \pm .003^{\mathrm{c}}$ & $1.32 \pm .003^{\mathrm{c}}$ & $1.46 \pm .001^{\mathrm{c}}$ \\
$8 \% \mathrm{Bp}$ & $0.89 \pm .001^{\mathrm{c}}$ & $0.96 \pm .006^{\mathrm{c}}$ & $1.16 \pm .002^{\mathrm{cd}}$ & $1.25 \pm .005^{\mathrm{d}}$ & $1.28 \pm .003^{\mathrm{d}}$ \\
$\mathrm{BHA}(\mathrm{mg} / \mathrm{kg})$ & $0.96 \pm .001^{\mathrm{c}}$ & $0.98 \pm .001^{\mathrm{c}}$ & $1.09 \pm .001^{\mathrm{d}}$ & $1.22 \pm .002^{\mathrm{d}}$ & $1.28 \pm .001^{\mathrm{d}}$ \\
\hline SD & 0.2048 & 0.1759 & 0.1513 & 0.2239 & 0.2946 \\
\hline
\end{tabular}

* mg malonaldehyde / $\mathrm{kg}$ sample

Mean \pm Standard deviation of three values

In a column, values have the same superscript letters are not significantly different by Dancen's test at $5 \%$ level

Bp $2 \%=$ ostrich nuggets with $2 \%$ broccoli powder

Bp 4\% = ostrich nuggets with $4 \%$ broccoli powder

Bp $6 \%=$ ostrich nuggets wih $6 \%$ broccoli powder

Bp $8 \%=$ ostrich nuggets with $8 \%$ broccoli powder

BHA = ostrich nuggets with butylated hydroxyl anisole $(150 \mathrm{mg} / \mathrm{kg})$

Sensory attributes of ostrich nuggets contained broccoli powder as affected by refrigerated storage at $4^{\circ} \mathrm{C}$ for 15 day :

As shown in Table (10), the sensory attributes were significantly $(p<0.05)$ affected during 15 day of refrigerated storage at $4^{\circ} \mathrm{C}$ and all the sensory parameter viz color, firmness, flavor, taste, texture, juiciness and overall acceptability followed a descending trend $(p<0.05)$ with increase in storage periods. As the storage days progressed all the sensory properties followed a significant $(p<0.05)$ decreasing trend, however, in between treatments and control sensory properties were comparable throughout the storage period. Table (10) show that ostrich nuggets made free from broccoli powder (control) had high color scores which significantly $(p<0.05)$ decrease after 15 day of refrigerated storage at $4^{\circ} \mathrm{C}$. This was propably due to the changes in the oxidation states of heam pigments or the interaction between amino amines and sugars in millared reaction (Hastings, 1989). The decrease in color score of ostrich nuggets with increase in storage period.

Firmness scores followed a decreasing trend throughout the period of refrigerated storage. A gradual decline of flavor of ostrich nuggets contained broccoli powder might be due to the strong flavor of broccoli expected loss of volatile flavor component from condiments and spices during refrigerated storage at $4^{\circ} \mathrm{C}$ of ostrich nuggets. The progressive decrease in flavor could be related to increase in thiobarbituric acid reacting substances value of meat products (Tarladgis et al. 1960).

Texture scores followed a decreasing trend during the period of refrigerated storage. The lower textural scores might be due to loss of free water during storage. Similar results were presented by Thomas et al. (2006) in buffalo meat nuggets during refrigerated storage. The overall acceptability scores of both control and the treated nuggets with broccoli powder decrease significantly $(p<0.05)$ as the refrigerated storage progressed. This decrease 
might be reflective of the decline in scores of color, flavor, juiceness, taste and texture attributes. These results agree with these mentioned by Bloukas et al. (1997) who reported that overall acceptability of meat products such as beef patties and frankfurter was decreased as the storage time extended.

Table (10): Changes in sensory properties of ostrich nuggets contained broccoli powder as affected by refrigerated storage at $4^{\circ} \mathrm{C}$ for 15 day

\begin{tabular}{|c|c|c|c|c|c|c|c|}
\hline Sample & $\begin{array}{c}\text { Color } \\
(10)\end{array}$ & $\begin{array}{c}\text { Firmness } \\
(10)\end{array}$ & $\begin{array}{c}\text { Flavor } \\
(10)\end{array}$ & $\begin{array}{c}\text { Taste } \\
(10)\end{array}$ & $\begin{array}{c}\text { Texture } \\
(10)\end{array}$ & $\begin{array}{c}\text { Juiciness } \\
\text { (10) }\end{array}$ & $\begin{array}{c}\text { Overall } \\
\text { acceptability } \\
\text { (10) }\end{array}$ \\
\hline Control (0\%) & $8.19 \pm .17^{a}$ & $8.22 \pm .12^{a} 7$ & $34 \pm .11^{\mathrm{a}}$ & $7.19 \pm .13^{\mathrm{a}}$ & $7.18 \pm .13^{\mathrm{a}}$ & $7.33 \pm .14^{\mathrm{a}}$ & $7.86 \pm .16^{\mathrm{a}}$ \\
\hline Bp 2\% & $7.32 \pm .13^{b}$ & $7.21 \pm .09^{b} 7$ & $.15 \pm .13^{b}$ & $6.53 \pm .16^{\mathrm{b}}$ & $7.03 \pm .16^{b}$ & $7.15 \pm .11^{\mathrm{b}}$ & $7.26 \pm .00^{\mathrm{b}}$ \\
\hline Bp 4\% & $7.17 \pm .00^{c}$ & $6.44 \pm .10^{\mathrm{C}} 6$ & $25 \pm .16^{c}$ & $6.36 \pm .13^{b}$ & $6.51 \pm .16^{c}$ & $7.03 \pm .09^{b}$ & $7.02 \pm .11^{c}$ \\
\hline Bp 6\% & $6.41 \pm .13^{\mathrm{d}}$ & $6.26 \pm .08^{d} 6$ & $19 \pm .12^{d}$ & $6.09 \pm .16^{c}$ & $6.22 \pm .03^{c}$ & $6.26 \pm .00^{c}$ & $6.33 \pm .06^{\mathrm{d}}$ \\
\hline Вp 8\% & $6.32 \pm .19^{e}$ & $6.09 \pm .13^{\mathrm{e}} 5$ & $.86 \pm .100^{e}$ & $5.38 \pm .09^{d}$ & $5.87 \pm .10^{d}$ & $6.05 \pm .12^{d}$ & $5.88 \pm .16^{\mathrm{e}}$ \\
\hline $\mathrm{BHA}$ & $8.22 \pm .03^{\mathrm{a}}$ & $8.13 \pm .12^{\mathrm{a}} 7$ & $.66 \pm .16^{a}$ & $7.03 \pm .21^{\mathrm{a}}$ & $7.26 \pm .22^{\mathrm{a}}$ & $7.31 \pm .13^{\mathrm{a}}$ & $7.76 \pm .12^{\mathrm{a}}$ \\
\hline
\end{tabular}

Mean \pm Standard deviation of ten values

In a column, values have the same superscript letters are not significantly different at $5 \%$ level

Bp $2 \%=$ ostrich nuggets with $2 \%$ broccoli powder

Bp $4 \%=$ ostrich nuggets with $4 \%$ broccoli powder

Bp $6 \%=$ ostrich nuggets wih $6 \%$ broccoli powder

Bp $8 \%=$ ostrich nuggets with $8 \%$ broccoli powder

BHA = ostrich nuggets with butylated hydroxyl anisole $(150 \mathrm{mg} / \mathrm{kg})$

\section{Conclusions :}

From the previous results, it could be concluded that broccoli powder is a good source of natural antioxidant, so addition to meat products and foods may prevent against oxidative deterioration because of the high content of antioxidant compounds such as polyphenols and flavonoids. Thus, it can be used as natural antioxidants insteated of synthetic antioxidants which have negative effect on human health

\section{REFERENCES}

Abou-Arab, E.A. and F.M. Abu-Salem. 2010. Effect of natural antioxidants on the stability of ostrich meat during storage. Grasas Y Aceites 61(1): 102- 108.

Alsuhaibani, A.M.A. 2013. Effect of broccoli on the antioxidant activity of experimental rats ingested thermally oxidized oil. Nature \& Sci., 11(12): 17.

Amarowicz, R., R. Pegg, P. Rahimi-Moghaddam, B. Barl and J. Weil. 2004. Free-radical scavenging capacity and antioxidant activity of selected plant species from the Canadian prairies. Food Chem., 84:551-562. 
A.O.A.C. 2000. Official Methods of Analysis. The Association of Official Analytical Chemists17th ed. Gaithersburg M D.USA.

A.O.A.C. 2005. Association of Official Method of Analysis, 18 th Ed. of A.O.A.C. International. Published by A.O.A.C. International, Maryland, USA.

Banerjee, R., A.K. Verma, A.K. Das, V. Rajkumar, A.A. Shewalkar and H.P. Narkhede. 2012. Antioxidant effects of broccoli powder extract in goat meat nuggets. Meat Sci., 91: 179-184.

Barbanti, D. and M. Pasquini. 2005. Influence of cooking conditions on cooking loss and tenderness of raw and marinated chicken breast meat. LWT., 38: 895-901.

Bennion, M. and B. Scheule. 2004. Introductory Foods. $12^{\text {th }}$ (Ed) Pearson Education, Inc., Upper Saddle River, New Jerssey. Pp: 187-189.

Berry, B.W. 1993. Fat level and freezing temperature effect sensory shear, cooking and composition properties of ground beef patties. J. Food Sci., 58: 34-37.

Borowski, J., A. Szajdek and E. J. Borowska. 2008. Content of selected bioactive components and antioxidant properties of broccoli (Brassica oleracea L.). European Food Research Technol., 246: 459-465.

Bhandari, S.R. and J. H. Kwak. 2014. Seasonal variation in phytochemicals and antioxidant activities in different tissues of various broccoli cultivars. African J. Biotechno., 13(4): 604-615.

Bhosale, S.S., A. K. Biswas, J. Sahoo, M. K. Chatli, D. K. Sharma and S. S. Sikka. 2011. Quality evaluation of functional chicken nuggets incorporated with ground carrot and mashed sweet potato. Food Sci. and Techn. Inter., 17: 0233-0237.

Bloukas, J.G., E. D. Panerase and G. C. Fournitzis. 1997. Sodium lactate and protective culture effects on quality characteristics and shelf life of low fat frankfurter produced with olive oil. Meat Sci., 45: 223-238.

Cano, A., J. Hernandez-Ruiz, F. Garcia-Canovas, M. Acosta and M. B. Arnao. 1998. An end-point method for estimation of the total antioxidant activity in plant material. Phytochemical Analysis, 9(4): 196-202.

Chanda, S. and R. Dave. 2009. In vitro models for antioxidant activity evaluation and some medicinal plants possessing antioxidant properties: An overview. African J. Microbiology Res., 3: 981-996.

Charoensiri, R., R. Kongkachuichai, S. Suknicom and P. Sungpuag. 2009. $\beta$-carotene, lycopene and a-tocopherol contents of selected Thai fruits.

Food Chem., 113: 202-207.

Chen, C. W. E. N. and C. H. I. T. Ho. 1995. Antioxidant properties of polyphenols extracted from green and black teas. J. Food Lipids 2:35-46.

Chung, Y.C., C. T. Chang, W. W. Chao, C. F. Lin and S. T. Chou. 2002. Antioxidative activity and safety of the $50 \%$ ethanolic extract from red bean fermented by Bacillus subtilis IMR-NKI .

J. Agric. Food Chem., 50: 2454-2458.

Cooper, R.G., H. Naranowicz, E. Maliszewska, A. Tennett and J. O. Horbancuk. 2008. Sex-based comparison of limb segmentation in ostriches aged 14 months with and without tibiotarsal rotation. J. South African Veterinary Asso., 79: 142-144. 
Da Porto, C., S. Calligaris, E. Celotti and M. C. Nicoli. 2000. Antiradical properties of commercial cognacs assessed by the DPPH test. J. Agric. Food Chem., 48(9): 4241-4245.

Dominguez-Perles,R., D. A. Moreno and C. G. Garcia-Viguera. 2012. Analysis of the tumoral cytotoxicity of green tea infusions enriched with broccoli. Food Chem., 132: 1197-1206.

Fahey, J.W., A. T. Zalcmann and P. Talalay. 2001. The chemical diversity and distribution of glucosinolates and isothiocyanates among plants. Phytochemistry 56:5-51.

Faller, A.L.K. and E. Fialho. 2009. The antioxidant capacity and polyphenol content of organic and conventional retail vegetables after domestic cooking. $\quad$ Food Res.Inter., 42: 210-215.

Farag, R. S., E. A. Mohamoud, A. M. Basuny and R. Ali. 2006. Influence of crude olive leaf on rat liver and kidney function. Inter.J. Food Tech., 41: 1-10.

Garcia, M.L., R. Dominguez, M. D. Galvez, C. Casas and M. D. Selgas. 2002. Utilization of cereal and fruit fibers in low fat dry fermented sausages. Meat Sci., 60: 227-236.

Hagerman, A.E., K. M. Riedl, G. A. Jones, K. N. Sovik, N. T. Ritchard, P. W. Hartzfeldd and T. L. Riechel. 1998. High molecular weight plant polyphenolics (tannins) as biological antioxidants. J. Agric. Food Chem., 46: 1887-1892.

Hastings, R.G. 1989. Comparison of the properties of gels derived from cod surimi and from unwashed and once washed cod mince. Inter. J. Food Sci. and Technol., 24 : 93-102.

Heimler, D., P. Vignolini and M. G. Dini. 2005. Antiradical activity and polyphenol composition of local Brassicaceae edible varieties. Food Chem., 99 : 464-469.

Hoffman, L.C. and F. D. Mellett. 2003. Quality characteristics of low fat ostrich meat patties formulated with either pork lard or modified corn starch, soy isolate and water. Meat Sci., 65: 869-875.

Hounsome, N., B. Hounsome, D. Tomos and G. Edwards-Jones. 2009. Changes in antioxidant compounds in white cabbage during winter storage.

Postharvest Biol. Technol., 52: 173-179.

Iqbal, S. and M. I. Bhanger. 2006. Effect of season and production location on antioxidant activity of Moringa oleifera leaves grown in pakistan. J. Food Composi. and Analy., 19: 544-551.

Jung, S., J. Choe, B. Kim, H. Yun, Z. A. Kruk and C. Jo. 2010. Effect of dietary mixture of gallic acid and linoleic acid on antioxidative potential and quality of breast meat from broilers. Meat Sci., 86: 520-526.

Kato, K., S. Terao, N. Shimamoto and M. Hirata. 1988. Studies on scavengers of active oxygen species. 1. Synthesis and biological activity of 2-Oalkylascorbicacids. J. Medicinal Chem., 31(4): 793-798.

Kim, J. S., J. S. Godber and W. Prinaywiwatkul. 2000. Restructured beef roasts containing rice bran oil an fiber influences cholesterol oxidation and nutritional profile. J. Muscle Food 11: 11-137. 
Kim, S.J., S. C. Min, H. J. Shin, Y. J. Lee, C. A. Reum, S. Y. Kim and J. Han. 2013. Evaluation of the antioxidant activities and nutritional properties of ten edible plant extracts and their application to fresh ground beef. Meat Sci., 93: 715-722.

Kramer, A. and B. A. Twigg. 1970. Quality control for the food industry 3th. AVI Publishing Co. Westport Conn. London. England.

Krishnaraju, A.V., C. V. Rao, T.V. N. Rao, K. N. Reddy and G. Trimurtulu. 2009. In vitro and In vivo antioxidant activity of Aphanamixis polystachya bark. Amer. J. Infectious Diseases, 5 (2): 60-67.

Kumar, M. and B. D. Sharma. 2004. The storage stability and textural, physico-chemical and sensory quality of low-fat ground pork patties with carrageenan as fat replacer. Internat. J. Food Sci.and Techn., 39: 3142.

Kumar,P., M. K. Chatli, N. Mehta, D. Kumar and J. Sahoo. 2013. Oxidative stability and quality attributes of emu meat nuggets incorporated with selected levels of broccoli (Brassica oleracea) powder. J. Meat Sci. \& Techn., 1(3): 83-90.

Mehta, N., S. S. Ahlawat, D. P. Sharma and R. S. Dabur. 2013. Novel trends in development of dietary fiber rich meat products-a critical review. J. Food Sci. and Techno., DOI 10.1007/s13197-013-1010-2.

Melo, E.A., J. M. Filho and N. B. Guerra. 2005. Characterization of antioxidant compounds in aqueous coriander extract (Coriandum sativum L.). Lebensm.- Wiss. U.- Technol., 38: 15-19.

Mendiratta, S.K., A. T. Shinde and B. G. Mane. 2013. Effect of added vegetable (carrot, radish and capsicum) as functional ingredients in mutton nuggets.

J. Meat Sci. and Techno., 1(2): 71-76.

Monero, D.A., S. Perez-Balibrea and F. Ferreres. 2010. Acylated anthocyanins in broccoli sprouts. Food Chem., 123(2): 358-363.

Morrissey, P.A., P. J. A. Sheehy, K. Galvin, J. P. Kerry, D. J. Buckley. 1998. Lipid stability in meatand meat products. Meat Sci 49:S73-86.

Morsi, H.H.H. 1988. Studies of freezing preservation of meat. Ph.D. Thesis, Fac. Agric., Cairo Univ. Egypt.

Muchuweti, M., E. Kativu, C. H. Mupure, C. Chidewe, A. N. Ndhlala and M. A. N. Benhura. 2007. Phenolic composition and antioxidants properties of some spices. American J. Food Technol., 2: 414-420.

Mukherjee, S., H. Gangopadhyay and D. K. Das. 2008. Broccoli: a unique vegetable that protects mammalian hearts through the redox cycling of the thioredoxin superfamily. J. Agric.Food Chem., 56(2): 609-617.

Namiki, M. 1990. Antioxidants / Antimutagenes in foods. Critical Review in Food Science and Nutrition, 29: 273-279.

Olga, N., C. Baypoli, D. L.'Nchez-Machado, C. Bueno-Solano, A. Jose, N. E. Lum, C. M. Reyes-Moreno and J. L.' Pez-Cervantes. 2009. Biochemical composition and physicochemical properties of broccoli flours. Int. J. Food Sci. and Nutr., 60(S4): 163-173.

Oyaizu, M. 1986. Studies on products of browning reactions: Antioxidative activities of products of browning reaction prepared from glucoseamine. Japanese J. Nutri., 44, 307-315. 
Picchi, V., C. Migliori, R. Lo Scalzo, G. Campanelli, V. Ferrai, L.F. Di Cesare. 2012. Phytochemical content in organic and conventionally grown Italian cauliflower. Food Chem., 130: 501-509.

Podsedek, A. 2007. Natural antioxidants and antioxidant capacity of Brassica vegetables : a review. Swiss Society of Food Sci. \& Tech., 40: 1-11.

Pourcel, L., J. M. Routaboul, V. Cheynier, L. Lepiniec and L. Debeaujon. 2007. Flavonoid oxidation in plants: from biochemical properties to physiological functions. Trends Plant Sci., 12: 29-36.

Qwele, K. 2011. Antioxidant activity and the quality of meat from goats and broilers supplemented with Moringa (Moringa oleifera) leaves. M.Sc. Thesis, Fac. Sci. \& Agric., Fort Hare Univ., Alice, South Africa.

Rabaneda, F.S., O. Jauregui, R. M. L. Raventos, J. Bastida, V. Francesc and C. Calles. 2003. Identification of phenolic compoundsi $n$ artichoke waste by high performance liquid chromatography-tendem mass spectrometry. J. Chrom., A 1008: 57-72.

Reglero, R.G.J., G. J. J. Tabera, E. M. E. Jbanez, L. S. Lopez-Sebastian, M. E. Ramos, S. L. Ballester and M. J. M. Bueno. 1999. Proceso de extraccion con fluidos superciticos para la produccion de antioxidants naturals $\mathrm{Y}$ antioxidante obienido mediante dicho procese. Patente Espanola, 2: 128-996.

Rehab, M.M. 2002. Effect of some food additives on the shelf life of refrigerated beef meat. Ph.D. Thesis, Fac. Agric., Cairo Univ., Egypt.

Rosicka-Kaczmarek, J. 2004. Polifenole jako naturalne antyoksydanty w zywnosci (Polyphenols as natural antioxidants in food). Przegl. Piek. Cuk., 6: 12-16 (in polish).

Sales, J. 1998. Fatty acid composition and cholesterol content of different ostrich muscles. Meat Sci., 49, 489-492.

Samarth, M.R., M. Panwar, M. Kumar, A. Soni, M. Kumar and A. Kumar. 2008. Evaluation of antioxidant and radical-scavenging activities of certain radio protective plant extracts. Food Chem., 106: 868-873.

Santhi, D. and A. Kalaikannan. 2014. The effect of addition oat flour in low fat chicken nuggets. J. Nutr. Food Sci., 4:1-4.

Sikora, E., E. Cieslik and K. Topolska. 2008. The sources of natural antioxidants. Acta Sci. Pol. Technol. Aliment 1:5-17.

Singleton, V.L. and J. A. Rossi. 1965. Colorimetry of total phenolics with phosphomolybdic- phosphotungstic acid reagents. Am. J. Enol. \& Viticult., 16: 144-158.

Siu, G.M. and H. H. A. Draper. 1978. A survey of the malonaldehyde content of retail meats and fish. J. Food Sci., 43: 1147-1149.

Shirwaikar, A., K. Rajendran and I. S. R. Punitha. 2006. In vitro antioxidant studies on the benzyl tetra - tsoquinoline alkaloid berberine. Biological and Pharmaceutical Bulletin, 29(9): 1906-1910.

Sreelatha, S. and P. R. Padma. 2009. Antioxidant activity and total phenolic content of Moringa oleifera leaves in two stages of maturity. Plant Foods Human Nutri., 64: 303-311.

SPSS .1997. Spss users Gide Statistics version 8. Copy right Spss Inc., USA, Washington, D.C. USA.

Tarladgis, B., B. M. Watts, M. T. Younathan and L. Dugan. 1960. 
A distillation method for the quantitative determination of malanoldehyde in muscle foods.

J. Am. Oil Chem. Soc., 37:44-48.

Thomas, R., A. S. R. Anjaneyulu and N. Kondaiah. 2006.

Quality and shelf life evaluation of emulsion and restructured buffalo meat nuggets at cold storage $\left(4 \pm 1^{\circ} \mathrm{C}\right)$ Meat Sci., 72:373-379.

Viuda-Martos, M., Y. Ruiz-Navajas, J. Fernandez-Lopez and J. A. PerezAlvarez. 2010. Effect of orange dietary fiber, oregano essential oil and packaging conditions on shelf life of bologna sausages. Food Control, 21: 436-443.

Witte, V. C., G. F. Krause and M. F. Bailey. 1970. A new extraction method for determining 2-thiobarbituric acid values of pork and beef during storage. J. Food Sci., 35, 582-585.

Xiong,Y.L., A. H. Cantor, A. J. Pescatore, S. P. Blanchard and M. L. Straw. 1993. Variations in muscle chemical compositions, $\mathrm{pH}$ and protein extractability among eight different broiler crosess. Poultry Sci., 72: 583-588.

Zhishen, J., T. Mengceng and W. Jianming. 1999. The determination of flavonoid contents in mulberry and their scavenging effects on superoxide radicals. Food Chem., 64: 555-559.

Zarasvand, S.A., M. Kadivar, M. Aminlari and S. S. Shekarforoush. 2012. A comparative study of physic-chemical and functional properties and ultrastructure of ostrich meat and beef during aging. J. Food, 10(3): 203-209.

تأثير إضافة مسحوق البروكلى على النشاط المضاد للأكسدة وخصائص الجودة

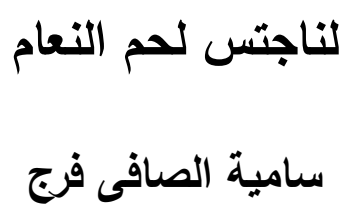

$$
\begin{aligned}
& \text { قسم علوم وتكنولوجيا الأغذية - كلية الأقتصاد المنزلى - جامعة الأزهر - طنطا - مصر } \\
& \text { يوجد طلب فى الآونة الأخيرة على أستعمال المواد المضادة للأكسدة الطبيعية سواء من ناحية تفضيل } \\
& \text { المستهلك أو من الناحية الصحية والمرتبطة بإستعمال مضادات الأكسدة الصناعية . } \\
& \text { تهدف هذه الدراسة إلى تقييم المركبات المضادة للأكسدة فى مسحوق البروكلى وأمكانية استخدامها كمواد مضاد } \\
& \text { للأكسدة طبيعية فى إنتاج ناجتس لحم النعام. تم دراسة تأثير أضافة مسحوق البروكلى عند مستويات مختلفة (صفر }
\end{aligned}
$$

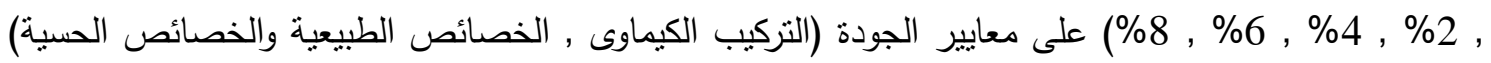

$$
\begin{aligned}
& \text { لناجتس لحم النعام وذلك مقارنة بالعينات الكنترول والناجتس المعامل ب BHA (150 مجم / كجم). تم تقييم } \\
& \text { الثبات التأكسدى لمسحوق البروكلى وناجنس لحم النعام المضاف إليه مسحوق البروكلى بواسطة طرق كسح } \\
& \text { الأصول الحرة ABTS , DPPH , والقوة الأختزالية. أدت زيادة أضافة مسحوق البروكلى إلى زيادة معنوية > p) }
\end{aligned}
$$


(0.05 فى محتوى الرماد والألياف وإنخفاض محتوى الرطوبة , البروتين والدهن. كما أظهرت النتائج أن مسحوق البروكلى به كميات مرتفعة من الفينولات العديدة , الفلافونويدات , والجليكوسيدات $(17.955$, 56.56 , 9.15 مجم / جم على التوالى ). أظهرت النتائج أن مسحوق البروكلى مرتبط بأكسدة الدهون فى ناجنس لحم النعام والمقاس بواسطة قيمة ال TBA أدت أضافة 8\% مسحوق بروكلى إلى ناجتس النعام إلى الحصول على أقل قيمة لحمض الثيوباربنيوريك مقارنة بالعينات الكنترول والناجتس المعامل ب BHA ـ أوضحت النتائج أن أضافة مسحوق البروكلى أدى إلى إنخفاض معنوى فى الفقد فى الطبخ والأنكماش وزيادة عائد الطبخ فى ناجتس لحم النعام

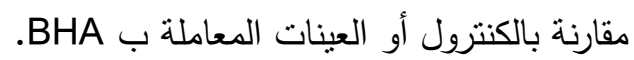
أنشارت النتائج أن ناجنس لحم النعام المحتوى مسحوق البروكلى (خاصة 8\%) سجل أعلى نشاط مضاد للأكسدة وذللك من خلال أرتفاع قيم ABTS , DPPH , القوة الأختزالية مقارنة العينات الكنترول وناجتس BHA ـ أوضحت نتائج التقييم الحسأن كل مستويات الأضافة حازت قبول جيد فى كل الخصائص الحسية مقارنة بالكنترول. لذلك بمكن أستخدام مسحوق البروكلى بدلا من مضادات الأكسدة الصناعية حيث أضافة مسحوق البروكلى حتى بنسبة 8\% لم يكن لها نأثثر عكسى على الخصائص الحسية أو بدون التأثير على قبول ناجنس لحم النعام. كان معدل

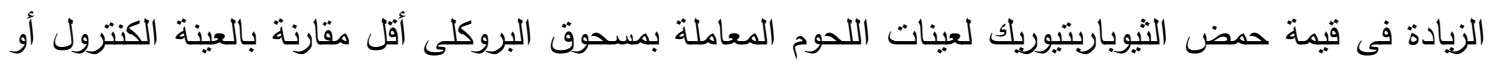
المعاملة ب BHA أوضحت النتائج حدوث زيادة فى قيم حمض الثيوباربنيوريك وإنخفاض فى درجات التقييم الحسى خلال التخزين المبرد على 40م لمدة 15 يوم, لذا توصى الدراسة بأستخدام مسحوق البروكلى كمصدر لمضادات الأكسدة الطبيعية لزيادة فترة صلاحية المنتجات الغذائية المحتوية دهون وزيوت والتى تكون آمنة ويمكن أن تؤدى لفوائد صحية للمستهلك . 
